Revue d'histoire de l'Amérique française

REYUE D.HISTOIRE DE L'AMÉRIQUE FRANÇAISE

Département des littératures de l’Université Laval, sous la direction de Clément Moisan, Livres et Auteurs québécois 1974. Revue critique de l'année littéraire. Les Presses de l'Université Laval, Québec, 1975. 415 p. Livres et Auteurs québécois 1975 (...), 1976. 338 p. $\$ 5.00$

\title{
Pierre Savard
}

Volume 30, numéro 3, décembre 1976

URI : https://id.erudit.org/iderudit/303556ar

DOI : https://doi.org/10.7202/303556ar

Aller au sommaire du numéro

\section{Éditeur(s)}

Institut d'histoire de l'Amérique française

\section{ISSN}

0035-2357 (imprimé)

1492-1383 (numérique)

Découvrir la revue

Citer ce compte rendu

Savard, P. (1976). Compte rendu de [Département des littératures de l'Université Laval, sous la direction de Clément Moisan, Livres et Auteurs québécois 1974. Revue critique de l'année littéraire. Les Presses de l'Université Laval, Québec, 1975. 415 p. Livres et Auteurs québécois 1975 (...), 1976. 338 p. \$5.00]. Revue d'histoire de l'Amérique française, 30(3), 436-437.

https://doi.org/10.7202/303556ar services d'Érudit (y compris la reproduction) est assujettie à sa politique d'utilisation que vous pouvez consulter en ligne.

https://apropos.erudit.org/fr/usagers/politique-dutilisation/ 
Département des littératures de l'Université Laval, sous la direction de Clément Moisan, Livres et Auteurs québécois 1974. Revue critique de l'année littéraire. Les Presses de l'Université Laval, Québec 1975, 415 p. Livres et Auteurs québécois 1975 (...), 1976, 338 p. $\$ 5.00$.

Pour qui veut suivre la production historiographique d'ici, abondante et bien inégale, les guides critiques restent peu nombreux. Notre Revue fait un bel effort pour recenser ce qui mérite de l'être, non parfois sans retards ni oublis, pour ne rien dire d'accidentels comptes rendus ratés qui pèchent par indulgence ou esprit de dénigrement. Le curieux du mouvement historique doit compléter par des périodiques divers depuis la Canadian Historical Review qui ne couvre qu'une partie de la production jusqu'à la Presse de Montréal en passant par Histoire sociale et Le livre canadien.

Bon an mal an, Livres et Auteurs québécois recense les œuvres d'histoire marquantes à l'intérieur de sa grande fresque de la production littéraire. Serge Gagnon, bien connu des lecteurs de notre Revue, est responsable de la pléthorique section des essais depuis cinq ans déjà. L'examen des comptes rendus des deux dernières années fait voir pourquoi cet instrument est devenu indispensable aux historiens d'ici. Les comptes rendus sont en général critiques et signés de noms qui commandent le respect dans leur champ: F. Ouellet, L. Campeau, P. Sylvain, R. Durocher, R. Jones, S. M. Trofimenkoff, J.-L. Roy, C. Jaenen, P.-A. Linteau, J.-C. Dubé, P. Hurtubise, 
sans oublier S. Gagnon. Les spécialistes de sciences humaines voisines tels A. Vachet, F. Dumont, J.-C. Falardeau, R. Arès, sont volontiers mis à contribution. Depuis quelques années, le responsable de la section des essais livre ses impressions générales et explicite ses critères de sélection de la production annuelle. C'est là une excellente initiative de même que la nouvelle catégorie créée en 1975 pour les ouvrages qui ne méritent qu'une «fiche bibliographique».

Centre de recherche en

PierRe Savard

civilisation canadienne-française

Université d'Ottawa 